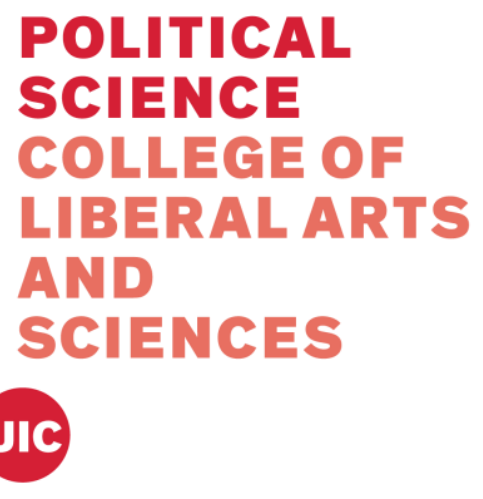

\title{
Affirmative Action for Whom? An Experiment on Latino Affirmative Action Policy Preferences
}

\author{
Eduardo Salinas \\ The University of Illinois at Chicago \\ 1007 W. Harrison Street \\ 1102 Behavioral Science Building, MC 276 \\ Chicago, Illinois 60607 \\ Email:ESalin5@uic.edu \\ Twitter: @ESalinas80
}

\begin{abstract}
$\underline{\text { Abstract }}$
Why do Latinos show high opposition toward affirmative action, a policy that benefits them as a group? Using data from a nationally representative survey experiment, I find that racial prejudice drives Latino affirmative action policy preferences to mirror those of whites - with caveats. My results show that whites oppose affirmative action for both blacks and Latinos, and Latinos oppose affirmative action for blacks. Both white and Latino opposition to affirmative action is a function of their anti-black racial prejudice. However, I also find evidence that Latino policy attitudes toward affirmative action are also a function of Latino identity. Specifically, among Latinos with a strong Latino in-group identity, we see evidence of a solidarity effect - affirmative action support for both Latinos and blacks.
\end{abstract}




\section{Introduction}

Affirmative action policies seek to prevent and correct systematic racial/ethnic discrimination in the United States across hiring and education. Research finds that Latinos receive substantial educational and career benefits from affirmative action, benefits that would otherwise not exist without such policies (Blume \& Long 2014; Munguia 2015). However, despite the opportunities that Latinos receive from affirmative action, research finds mixed results on whether or not the majority of Latinos support affirmative action. For example, a 1996 study by Citrin tracks Latino affirmative action preferences from 1986 to 1994. Citrin finds a slight majority of Latinos (56\%) opposed affirmative action policies in 1986 and 1988. In 1990, Latino opposition fell slightly below a majority to $46 \%$, before returning to a majority opposition of $60 \%$ in 1992 . Two years later, $71 \%$ of Latinos opposed affirmative action - a greater than two-thirds majority opposition (Citrin 1996: 43).

More recent data show that a majority of Latinos steadily oppose affirmative action throughout the past two decades since Citrin's 1996 study. Figure 1 shows the percentage of Latinos either opposing or srongly opposing affirmative action from years $2004-2018$. Throughout this recent twelve-year period, the percentage of Latinos who either "opposed or strongly opposed" affirmative action ranged from a high of $81 \%$ in 2006 to a low of $64 \%$ in $2010 .{ }^{1}$ Latino affirmative action policy preferences never reached majority support. Why would this be the case?

\footnotetext{
${ }^{1}$ Data derive from the General Social Survey, and can be reproduced at the GSS Data Explorer webpage, found here: https://gssdataexplorer.norc.org/
} 


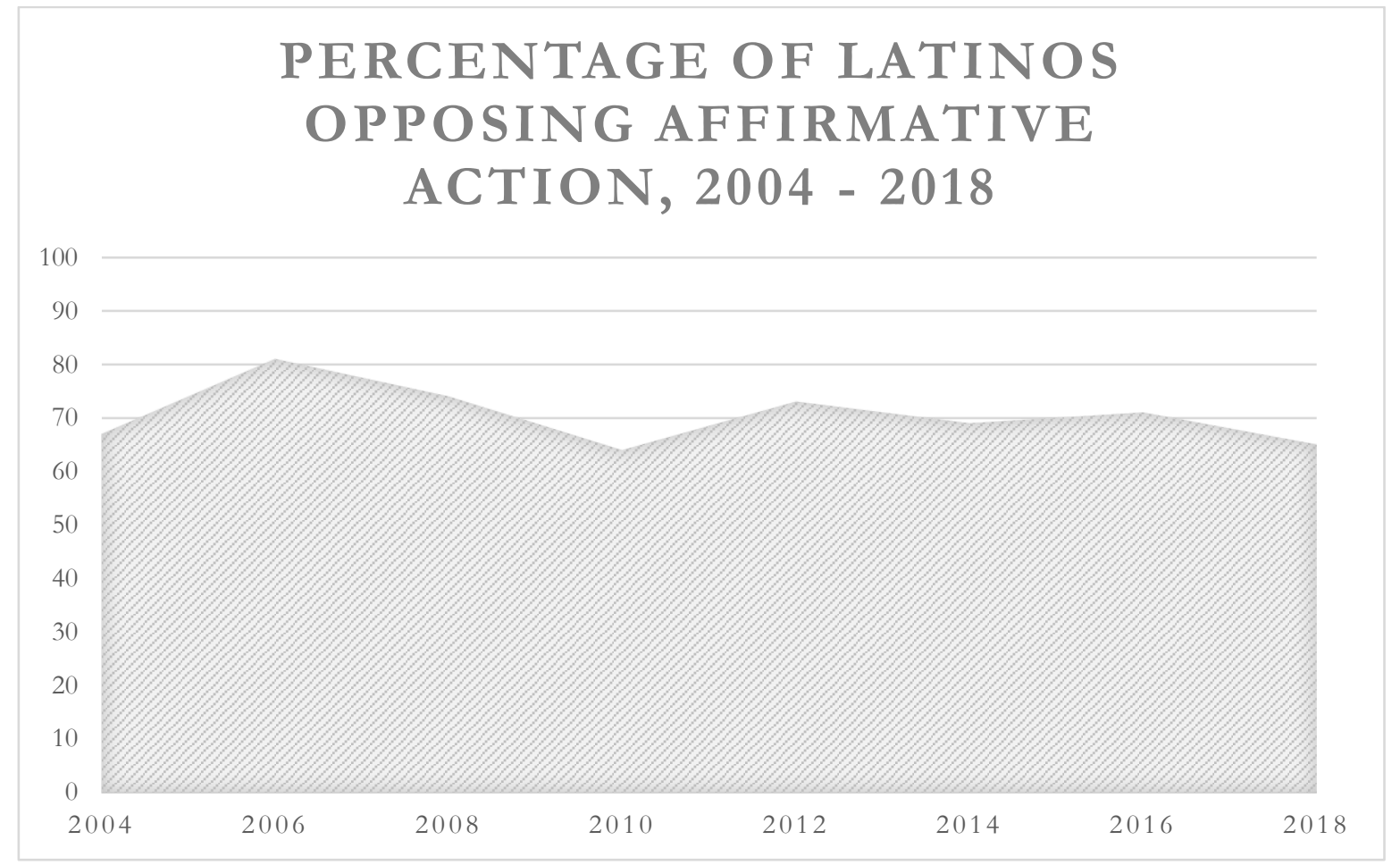

A large scholarship on individual policy preferences argues that direct beneficiaries of policies should display the highest support for the programs benefiting them (Bobo 1998; Weeden \& Kurzban 2017). Conversely, groups who do not benefit from specific policies will display the lowest support for them (Campbell et al. 1960; Kluegel \& Smith 1983). Affirmative action policy preferences among non-Hispanic whites, and among non-Hispanic blacks, largely follow these expectations. Non-Hispanic whites, as a group, consistently show the lowest levels of support for affirmative action (Hughes 1997), while blacks consistently show high levels of support for affirmative action (Kravitz \& Klineberg 2000). The expectation, then, is that Latinos should also support affirmative action policies since they too are beneficiaries. However, they do not.

The majority of what we know regarding policy preferences toward affirmative action derives from the study of non-Hispanic whites (Krysan 2000). Studies show that racial prejudice is the most consistent and substantial predictor of preferences toward affirmative action among non- 
Hispanic whites (Bobo et al., 1997; Tuch \& Hughes 2011). Moreover, scholars show that the influence of racial resentment among whites extends to a variety of other policy areas such as gun control (Filindra \& Kaplan 2016), and healthcare (Tesler 2012). However, scholars have failed to entertain how minority-on-minority racial prejudice may also influence policy preferences.

This article presents experimental evidence showing that anti-black racial resentment among Latinos is a significant driver of Latino opposition to affirmative action policies. This occurs when blacks are framed as the beneficiary, but not the case when Latinos are the beneficiary. Moreover, I find Latino in-group identity significantly drives Latino affirmative action policy preferences.

\section{Literature Review}

As previously mentioned, a large literature links white opposition to affirmative action policies with anti-black racial prejudice (Kinder \& Sanders 1996; Sears \& Henry 2003; Sears et al. 1997). Yet, some scholars have explicitly rejected anti-Black racial prejudice as a direct predictor of Latino policy preferences. For example, when studying to what extent Whites, Latinos, blacks, and Asians perceive themselves to be in competition with one another, Lopez \& Pantoja (2004) state:

“...it makes little sense to argue that African Americans, Latinos, or Asian Americans might dislike affirmative action programs because they are prejudiced (blatantly or symbolically) toward a particular racial minority group or perceive themselves to be locked in a zero-sum competition with some out-group" (635).

However, there are both historical and theoretical reasons why we would expect Latinos to show racial prejudice against blacks, and for this prejudice to play a part in Latino policy preferences. The history and legacy of colorism in Latin America (Telles 2014), the privileged position whites have held in American society (Haney-Lopez 2006), and the assimilation strategies of previous immigrant groups coming to the U.S. from Italy, Ireland, and other nations, all lay the groundwork for the probability of racist views to exist among Latino immigrants and their descendants. 


\section{Historical Determinants of Latino Anti-black Prejudice}

First, racism based on skin color is not unique to the United States. The people who emigrate from Latin America come from countries with prejudicial legacies of their own and bring with them preexisting racial attitudes. Most notably among these is colorism, defined by negative prejudice against peoples of darker phenotypes and favorability toward peoples of lighter phenotypes $^{2}$ (Andrews 2004; Dixon \& Telles 2017; Telles \& Paschel 2014). The remnants of “colorism" in Latin America remain strong (Cuevas \& Jackson 2004; Lancaster 1991; Lipschutz 1972; Telles 2014) and Latinos carry the legacy of colorism with them when migrating to the U.S. (Uhlmann et al. 2002). The influence of colorism is further compounded in the context of the United States. In the U.S., successfully identifying oneself with "whiteness" bestows a wide range of social, political, and economic benefits (Haney-Lopez 2006). This has historically had important consequences for immigrant groups seeking to assimilate into the American racial hierarchy.

During the late nineteenth century, for example, the benefits of whiteness served as real incentives for immigrant groups coming across the Atlantic from Europe to seek the label of "being white", to the extent that they could (Ignatiev 2012; Rieder 2009). The privileged position of whites in the U.S. continues to act as a pull to new immigrant groups today (Gross 2008). Furthermore, as immigrants seek inclusion into the dominant social group in the U.S. they also assume the attitudes and behaviors of the Anglo population. This acclimation among immigrants to the attitudes and behaviors of the dominant social group has been documented by historians (Gans 1979; Gordon 1964) and public opinion scholars alike (Branton 2007). The history of Latino activist groups in the U.S. shows they too have sought the same inclusion into whiteness as previous immigrant groups

\footnotetext{
${ }^{2}$ It is important to note that colorism is not the same as racism. Colorism occurs not only across people of different races but can also be found among people of the same race and/or ethnicity.
} 
before them. This is particularly true in the Mexican-American fight for equal access to education (Marquez 1993; San Miguel 1987).

Throughout the 1940s and 1950s, Mexican-American civil rights lawyers actively pursued a strategy of seeking legal identification as "white" as a way of ensuring protection against discrimination and the assurance of equal rights (San Miguel 1987). Throughout the pre-civil rights era, the Latino struggle for equality consisted not only of seeking identification with whiteness but also of maintaining a skeptical distance from blacks (Foley 2010). The efforts of Latinos to seek recognition as white eventually succeeded, although the implementation of this legal recognition did not provide the intended outcome. For example, shortly after the Brown v. Board of Education verdicts of 1954 and 1955 local governments began "integrating” schools by placing Latino and Black students together, while keeping Anglo students set apart. This led Mexican-American strategists to regroup.

At first, investment in what was known as the "other White" legal strategy was so entrenched that Mexican-American legal teams first dismissed the usefulness of the Brown v Board rulings (Wilson 2003: 164). Eventually, however, they abandoned the "other White" strategy in favor of earning recognition as a separate ethnic group under the equal protection clause (San Miguel 2005). A battle which, in 1970, led to the first legal recognition of Mexican-Americans as a separate ethnic minority group on the basis of their language, religion, culture, and surnames (Cisneros 1970/1971). A decision later ratified by the U.S. Supreme Court in 1973.

\section{Theoretical Determinants of Latino Anti-black Prejudice}

Affirmative action is a policy area where realistic group conflict would expect tensions between minority groups competing for like resources (Sherif et al. 1961; Sherif 1988). Perceived group threat theory would expect these tensions may be further exacerbated when competing 
groups are of nearly equal size (Quillian 1995), as is the case with blacks and Latinos in the U.S. Public opinion scholarship has demonstrated the influence of anti-black racial stereotypes and prejudice Latino policy preferences. For example, Filindra and Kaplan (2017) find that, much like whites, Latinos who hold negative stereotypes of blacks as violent are opposed to restrictive gun policies and prefer more permissive gun laws. Krupnikov and Piston (2016) find evidence that U.S.born Latinos who hold unsympathetic feelings toward blacks are much more likely to oppose affirmative action policies. These studies, while they do not look at racial prejudice directly, do find that the structure of Latino policy preferences mirrors those of whites in some ways.

Other studies draw attention to matters of group identity. Social identity theory states that people may interact either as an individual or as members of their own groups (Tajfel \& Turner 1979). Scholars find additional drivers affecting Latino policy attitudes such as Latino group consciousness, Latino ethnic solidarity, and Latino linked-fate ${ }^{3}$ (Barreto et al. 2009; Knoll 2012; Sanchez \& Vargas 2016). The concept of "group consciousness" carries elements of in-group commonality, perceived discrimination (at the individual and group level), and a sense of shared political interests (Sanchez 2006; Sanchez \& Vargas 2016). Importantly, measures of Latino in-group affiliation have also been found to have a solidarity effect whereby Latinos view blacks not as competitors but partners in a mutual struggle (Sanchez 2008), and can even lead Latinos to recognize when discrimination toward blacks occurs (Hurwitz et al 2015).

In other words, far from expecting a strictly antagonistic stance toward blacks, there are also indicators that the presence of a high Latino in-group affiliation may drive a more cooperative view between Latinos and blacks. These findings together pose a substantial puzzle. On the one hand, scholars show evidence that Latino anti-black prejudice can mirror that found among whites,

\footnotetext{
${ }^{3}$ Group consciousness, ethnic solidarity, and linked fate have most extensively been used to study the immigration policy preferences of Latinos.
} 
reducing Latino support for policies seen to benefit blacks. Yet, on the other hand, there is also evidence showing Latinos can exhibit shared political interests with blacks as a function of their Latino in-group affiliation. I argue that the policy area of affirmative action, with benefits for both blacks and Latinos, provides a suitable ground for further understanding how the drivers of Latino policy preferences work.

Research shows that solidarity can occur not just among dominant groups but also among subordinate groups in society when all group members are relatively deprived (Rabbie \& Horwitz 1969). Subordinate groups cling to particular aspects of their in-group identity as possessing comparative advantages when compared to other groups in order to sculpt a more positive social image (Fiske \& Taylor 2013; Tajfel 1981; Tajfel \& Turner 1979). Furthermore, social psychology research finds that self-identity is heavily dependent on the intergroup context rather than fixed (Turner 1985). As immigrants and descendants of immigrants, Latinos will tend to weigh the benefits of ethnic identification with the competing drive of belonging to the "correct" group (Brewer 1991). In the U.S. social context, this means Latinos may face a real pull to become white, and recent research by Pew on census data shows more and more Latinos are self-identifying as white (Cohn 2014). Furthermore, the psychological research implies that Latinos who begin to identify as white will not only adopt the norms, customs, and preferences of whites (Hogg 2001) but will likely favor their new in-group identity over others.

Furthermore, studies also show that individuals on the margins of "whiteness" (who may self-identify as white but not yet be accepted as such by society at large) display less progressive racial views and seek to legitimize their inclusion into whiteness by downplaying racial differences and amplifying an ideology of colorblindness in race relations (Vargas 2014). Likewise, groups on 
the margins of whiteness are likely to experience stigmas that may cause them to disavow their ethnic identification even more strongly (McCoy \& Major 2003).

These factors taken into account together suggest the following hypotheses stating that Latino racial attitudes and their in-group identification are likely to be important factors in their preference toward affirmative action policies.

\section{Hypotheses}

H1: Latino affirmative action support increases when Latinos are the target group, compared to when Latino are not the target group.

H2: Latinos with higher levels of in-group identity show higher levels of affirmative action support than Latinos with lower levels of in-group identity when Latinos are the target group.

H3: Latino affirmative action support decreases when blacks are the target group, compared to when blacks are not the target group.

H4: Latinos with higher levels of racial resentment toward blacks show lower levels of affirmative action support than do Latinos with lower levels of racial resentment toward blacks.

H5: Latinos with higher levels of in-group identity show lower levels of affirmative action support than Latinos with lower levels of in-group identity when blacks are the target group.

\section{Methodology}

There are several limitations of research on affirmative action support largely based on the availability of reliable measures in public opinion data. One major drawback of the items found in major nationally representative surveys is that they present affirmative action with blacks as the beneficiary with no alternative framing. This is especially problematic when linking racial prejudice with measures of affirmative action policy support since the dependent variable includes a reference to blacks in the same item purporting to measure affirmative action support, making it difficult to separate whether the antagonism is toward the policy, the beneficiary, or both. 
Previous scholarship has proposed testing various framings of affirmative action as a remedy to the problem mentioned above (Bell 2019; Sidanius et al. 2000) This study presents a survey experiment testing affirmative action support across various framings regarding which groups benefit from the policy. This is important considering scholarship that shows even minor changes in framing can have major effects in the level of support a policy receives (Chong \& Druckman 2007; Tesler 2015), especially with frames involving race (Tesler 2017). This research tests two treatments against a control to determine whether and how outgroup prejudice and/or in-group favoritism drive affirmative action support among Latinos and among non-Hispanic whites. I test whether support for affirmative action differs if the program is framed as targeting an outgroup vs an ingroup. I also test whether respondents' racial priors (measured in terms of racial resentment) condition the main effect of the treatment. Lastly, I test how in-group and outgroup identification moderates differences in support for affirmative action among non-Hispanic whites and Latinos.

The survey experiment fielded on August 6-10, 2019 with a sample of 1,107 Latinos and 727 non-Hispanic whites. ${ }^{4}$ The sample provider was Lucid, an online panel provider. The sample was pre-stratified and the resulting completed interviews mirror the national population of Latinos and whites as reflected in the American Community Survey. The average interview length equaled approximately 18 minutes. The experiment followed a 1x3 design: a control group and two experimental conditions. Respondents randomly received one of the following three conditions:

\section{Generally speaking, to what degree do you support or oppose affirmative action programs designed to help} [Low-income people/Latinos/African-Americans] get better jobs and education?

Prior to the experimental treatment, respondents received the racial resentment questions, a battery designed to assess Latino in-group identity, and a similar battery addressing white racial

\footnotetext{
4 The large sample size for the experiment was determined based on a power analysis for a small effect $(p<0.05$, power of 0.8 ), and to ensure a broader subgroup representation by implementing gender within age quotas.
} 
identity. The analyses include controls for age, gender, education, income, partisan affiliation, and political ideology (see Appendix, Tables A2, A3, and A4 for the descriptive statistics of nonHispanic whites, Latinos, and by treatment, respectively).

The dependent variable was the level of affirmative action support, measured on a 4-pt scale ranging from "strongly support" to "strongly oppose". Responses were re-coded on a 0 to 1 ordinal scale with higher values indicating stronger support. All variables use a 0 to 1 scale, allowing the OLS coefficients to serve as relative maximum effects. The analysis includes ordered logistic regression models, which yield similar results as the OLS regression models.

\section{$\underline{\text { Results }}$}

Table 1 shows the main effect results of affirmative action support across both treatments for non-Hispanic whites and Latinos. Among non-Hispanic whites, both the Latino treatment and the black treatment lead to decreased support for affirmative action policies, relative to the control. We see a different outcome for Latinos; only the black treatment leads to lowered support for affirmative action policies. Both of these results are statistically significant at a p-value less than 0.01 . The Latino treatment alone has no positive or negative effect on Latino support for affirmative action. These results hold with the addition of control variables; please see Appendix Table A1. 


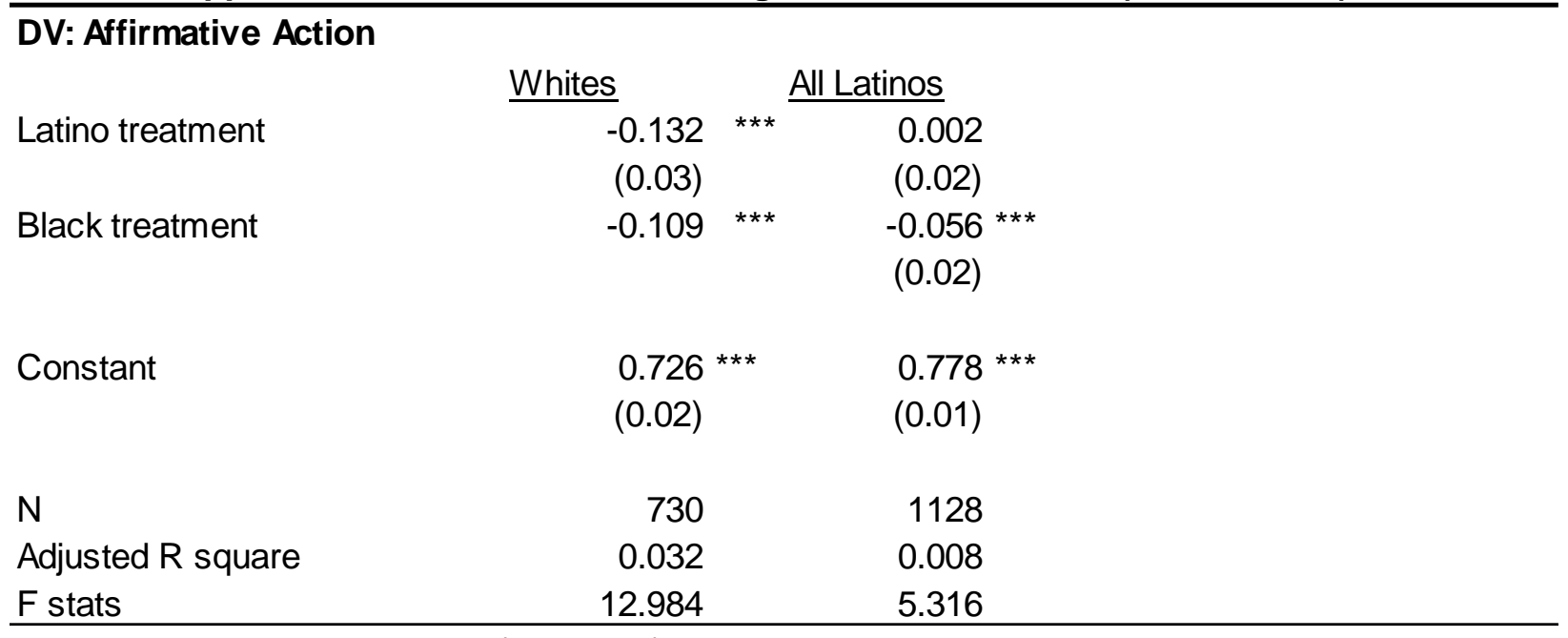

*** $p<0.01 ;{ }^{* *} p<0.05 ;{ }^{*} p<0.10$ (two tailed)

Robust standard errors in parentheses.

Table 2 shows five different models for non-Hispanic whites and Latino affirmative action support. The models show interactions with racial resentment measures for both non-Hispanic whites and Latinos, interactions with white ID measures for non-Hispanic whites and Latinos, and interactions with Latino ID measures for Latinos. We see that, among non-Hispanic whites, adding the factored racial resentment measure has a negative effect on affirmative action support when Latinos are the beneficiary. This indicates that for whites exposed to the Latino treatment, support for affirmative action decreases as a function of the strength of their racial resentment. Interestingly, however, this is not the case when whites receive the black treatment. For whites exposed to the black treatment, racial resentment produces no additional effect on the level of support for affirmative action policies. 
Table 2: Support for Affirmative Action among Whites and Latinos (Interactions)

\begin{tabular}{|c|c|c|c|c|c|}
\hline & $\begin{array}{c}\text { Whites } \\
\text { Treatment } \\
{ }^{*} \mathbf{R R}\end{array}$ & $\begin{array}{c}\text { Whites } \\
\text { Treatment } \\
{ }^{*} \text { white ID }\end{array}$ & $\begin{array}{c}\text { Latinos } \\
\text { Treatment } \\
\quad{ }^{*} \mathbf{R} \mathbf{R}\end{array}$ & $\begin{array}{c}\text { Latinos } \\
\text { Treatment } \\
{ }^{*} \text { white ID }\end{array}$ & $\begin{array}{c}\text { Latinos } \\
\text { Treatment } \\
{ }^{*} \text { Hisp ID }\end{array}$ \\
\hline \multicolumn{6}{|l|}{ DV: Affirmative Action } \\
\hline \multirow[t]{2}{*}{ Latino treatment } & -0.04 & $-0.186^{* \star *}$ & 0.017 & -0.019 & $-0.091 * *$ \\
\hline & $(0.05)$ & $(0.05)$ & $(0.03)$ & $(0.02)$ & $(0.04)$ \\
\hline \multirow[t]{2}{*}{ Black treatment } & -0.059 & $-0.125^{* * *}$ & 0.015 & $-0.057 * *$ & $-0.125 * * *$ \\
\hline & $(0.05)$ & $(0.05)$ & $(0.04)$ & $(0.02)$ & $(0.04)$ \\
\hline \multirow[t]{2}{*}{ Latino treatment ${ }^{\star}$ racial resentment } & $-0.172 * *$ & & -0.033 & & \\
\hline & $(0.08)$ & & $(0.07)$ & & \\
\hline \multirow[t]{2}{*}{ Black treatment *racial resentment } & -0.083 & & $-0.13^{*}$ & & \\
\hline & $(0.08)$ & & $(0.07)$ & & \\
\hline \multirow[t]{2}{*}{ Latino treatment*whitelD } & & 0.13 & & -0.019 & \\
\hline & & $(0.10)$ & & $(0.02)$ & \\
\hline \multirow[t]{2}{*}{ Black treatment *whitelD } & & 0.054 & & 0.063 & \\
\hline & & $(0.09)$ & & $(0.06)$ & \\
\hline \multirow[t]{2}{*}{ Latino treatment ${ }^{\star} H$ ispID } & & & & & $0.156^{* *}$ \\
\hline & & & & & $(0.06)$ \\
\hline \multirow[t]{2}{*}{ Black treatment ${ }^{*}$ HispID } & & & & & $0.14^{* *}$ \\
\hline & & & & & $(0.06)$ \\
\hline \multirow[t]{2}{*}{ Racial Resentment } & $-0.321^{* \star *}$ & $-0.409^{* * *}$ & $-0.276^{* * *}$ & $-0.338^{* * *}$ & $-0.299 * * *$ \\
\hline & $(0.06)$ & $(0.04)$ & $(0.05)$ & $(0.03)$ & $(0.03)$ \\
\hline \multirow[t]{2}{*}{ White Identity } & & -0.036 & & -0.025 & \\
\hline & & $(0.07)$ & & $(0.05)$ & \\
\hline \multirow[t]{2}{*}{ Hispanic Identity } & & & & & $0.12 * \star *$ \\
\hline & & & & & $(0.05)$ \\
\hline \multirow[t]{2}{*}{ Female } & 0.023 & 0.022 & 0.004 & 0.006 & 0.005 \\
\hline & $(0.02)$ & $(0.02)$ & $(0.02)$ & $(0.02)$ & $(0.02)$ \\
\hline \multirow[t]{2}{*}{ Education } & 0.044 & 0.045 & -0.021 & -0.017 & -0.05 \\
\hline & $(0.04)$ & $(0.04)$ & $(0.03)$ & $(0.03)$ & $(0.03)$ \\
\hline \multirow[t]{2}{*}{ Income } & -0.069 * & -0.068 * & -0.046 & -0.05 * & -0.041 \\
\hline & $(0.04)$ & $(0.04)$ & $(0.03)$ & $(0.03)$ & $(0.03)$ \\
\hline \multirow[t]{2}{*}{ Age 30-44 } & 0.05 & 0.052 * & 0.002 & 0.002 & 0.017 \\
\hline & $(0.03)$ & $(0.03)$ & $(0.02)$ & $(0.02)$ & $(0.02)$ \\
\hline \multirow[t]{2}{*}{ Age $45-64$} & 0.039 & 0.045 & -0.002 & 0.001 & 0.015 \\
\hline & $(0.03)$ & $(0.03)$ & $(0.02)$ & $(0.02)$ & $(0.02)$ \\
\hline \multirow[t]{2}{*}{ Age $65 p$} & 0.003 & 0.007 & -0.025 & -0.026 & 0.007 \\
\hline & $(0.03)$ & $(0.03)$ & $(0.05)$ & $(0.05)$ & $(0.05)$ \\
\hline \multirow[t]{2}{*}{ Party ID $(\mathrm{GOP}=1)$} & $-0.089 * *$ & $-0.091^{* *}$ & $-0.101^{\star * *}$ & $-0.098^{* * *}$ & $-0.075^{* * *}$ \\
\hline & $(0.04)$ & $(0.04)$ & $(0.03)$ & $(0.03)$ & $(0.03)$ \\
\hline \multirow[t]{2}{*}{ Ideology (Conservatism=1) } & $-0.087^{* *}$ & $-0.087^{* *}$ & $-0.096 * * *$ & $-0.095^{* * *}$ & -0.068 ** \\
\hline & $(0.04)$ & $(0.04)$ & $(0.03)$ & $(0.03)$ & $(0.03)$ \\
\hline \multirow[t]{2}{*}{ Constant } & $0.946^{* * *}$ & $1.004^{* * *}$ & $0.997^{* * *}$ & 1.026 *** & $0.918^{* \star *}$ \\
\hline & $(0.05)$ & $(0.05)$ & $(0.03)$ & $(0.03)$ & $(0.04)$ \\
\hline $\mathrm{N}$ & 727 & 727 & 1107 & 1107 & 1107 \\
\hline Adjusted R & 0.263 & 0.26 & 0.191 & 0.19 & 0.236 \\
\hline F stats & 20.94 & 19.223 & 21.042 & 19.496 & 25.43 \\
\hline
\end{tabular}

${ }^{\star * \star} p<0.01 ;{ }^{* \star} p<0.05 ;{ }^{*} p<0.10$ (two tailed)

Robust standard errors in parentheses.

For Latinos, we see the reverse. Racial resentment shows no moderating effect on

affirmative action support when exposed to the Latino treatment. However, we do see indication 
that racial resentment has a negative effect on Latino support for affirmative action when blacks are the beneficiaries. This suggests that for Latinos exposed to the black treatment, support for affirmative action decreases as a function of the strength of their racial resentment.

Table 2 also shows that interactions with the factored white identity measure have no effect on affirmative action support for both non-Hispanic whites and Latinos. However, we do see an interesting effect stemming from higher Latino identification levels. Latino ID is a statistically significant addition to the model, at a p-value less than 0.01. Furthermore, model 5 shows that a stronger Latino ID leads to higher affirmative action support overall. Moreover, the interaction results in the table also show a "solidarity effect" wherein Latinos having a high Latino in-group identity show increased support for affirmative action policies, relative to the control, when exposed to both the Latino treatment and the black treatment. This interaction effect is statistically significant at a p-value of less than 0.05 , and indicates a promising avenue for further research into this relationship.

\section{Discussion \& Conclusion}

This research falls in line with previous experimental investigations into affirmative action policy preferences (Bell 2019; Sidanius et al. 2000). This research finds that at-large, the affirmative action policy preferences of Latinos mirror those of whites. More specifically, and similar to the findings of Sidanius et al (2000), affirmative action support among both groups is a function of racial resentment. Furthermore, this research does not echo the findings of Bell (2019) showing that support or opposition stems from the "deservingness" of the target group. Instead, the main addition and takeaway we see from these results center on the primary role of in-group and outgroup affiliation for affirmative action policy preferences. 
For whites, out-group prejudice is the primary driver. For Latinos, out-group prejudice and in-group affiliation matter, and in unexpected ways. Though we find no support for H1, we do find support for H3 and H4 - a high out-group prejudice toward blacks drives down Latino support of affirmative action when blacks are the target. Furthermore, not only do we find support for H2, stating that Latinos with a high in-group Latino identity show higher support for affirmative action when Latinos are the target group, but we also find a solidarity effect in which Latinos with a higher Latino identity show higher affirmative action support for blacks as well. This is the opposite relationship expected in $\mathrm{H} 5$. Overall, the high level of heterogeneity among Latino affirmative action policy preferences presented here may signal why the policy preferences of Latinos sometimes seem ambiguous when measured as if they were a homogenous group with a tradition of cemented policy preferences.

Furthermore, this research demonstrates that the reference group matters when studying Latino affirmative action preferences. Since many of the nationally representative datasets scholars rely on to conduct public policy analyses frame the beneficiary group of affirmative action as being black, the data is likely not capturing the full picture of Latino affirmative action policy choice.

\section{$\underline{\text { References }}$}

Andrews GR. Afro-Latin America, 1800-2000. Oxford, UK: Oxford University Press, 2004.

Barreto, M A., S Manzano, R Ramirez and K Rim. "Mobilization, participation, and solidaridad: Latino participation in the 2006 immigration protest rallies." Urban Affairs Review 44 (2009): 736-764.

Blume, Grant H., and Mark C. Long. "Changes in levels of affirmative action in college admissions in response to statewide bans and judicial rulings." Educational Evaluation and Policy Analysis 36, no. 2 (2014): 228-252.

Bobo, Lawrence. "Race, interests, and beliefs about affirmative action: Unanswered questions and new directions." American Behavioral Scientist 41, no. 7 (1998): 985-1003.

"Social Responsibility, Individualism, and Redistributive Policies." In Sociological Forum, pp. 71-92. Eastern Sociological Society, 1991. 
Bobo, Lawrence, James R. Kluegel, and Ryan A. Smith. "Laissez-faire racism: The crystallization of a kinder, gentler, antiblack ideology." Racial attitudes in the 1990s: Continuity and change 15 (1997): 23-25.

Brewer, Marilynn B. "The social self: On being the same and different at the same time." Personality and social psychology bulletin 17, no. 5 (1991): 475-482.

Campbell, Angus, Philip E. Converse, Warren E. Miller, and Donald E. Stokes. The american voter. University of Chicago Press, 1980.

Chong, Dennis, and James N. Druckman. "Framing theory." Annu. Rev. Polit. Sci. 10 (2007): 103126.

Cisneros v. Corpus Christi Independent School District, 324 F. Supp. 599 (S.D. Tex. 1970), appeal docketed, No. 71-2397 (5th Cir. July 16, 1971).

Cohn, D'Vera. "Millions of Americans Changed Their Racial or Ethnic Identity from One Census to the Next." Pew Research Center (May 5, 2014) http://www.pewresearch.org/facttank/2014/05/05/millions-of-americans-changed-their-racial-or-ethnic-identity-from-onecensus-to-the-next/.

Dixon, Angela R., and Edward E. Telles. "Skin color and colorism: Global research, concepts, and measurement." Annual Review of Sociology 43 (2017): 405-424.

Entman, Robert M. "Manufacturing discord: Media in the affirmative action debate." Harvard international journal of press/politics 2, no. 4 (1997): 32-51.

Filindra, Alexandra, and Noah Kaplan. "Testing theories of gun policy preferences among Blacks, Latinos, and Whites in America." Social Science Quarterly 98, no. 2 (2017): 413-428.

'Racial resentment and whites' gun policy preferences in contemporary America." Political behavior, 38, no. 2 (2016): 255-275.

Fiske, Susan T., and Shelley E. Taylor. Social cognition: From brains to culture. Sage, 2013.

Foley, N. Quest for equality: The failed promise of black-brown solidarity. Harvard University Press, 2010.

Gans, Herbert J. "Second-generation decline: scenarios for the economic and ethnic futures of the post-1965 American immigrants." Ethnic and racial studies 15, no. 2 (1992): 173-192.

"Symbolic ethnicity: The future of ethnic groups and cultures in America." Ethnic and racial studies, 2, no. 1 (1979): 1-20.

Haney-Lopez, I. White by law: The legal construction of race. NYU Press, 1997.

Hechter, Michael. Internal Colonialism: The Celtic Fringe in British National Development. Routledge, 2017.

"Group formation and the cultural division of labor." American Journal of Sociology 84, no. 2 (1978): 293-318. 
Hogg, M. A. “A social identity theory of leadership.” Personality and social psychology review 5, no. 3 (2001): 184-200.

Hurwitz, J., Peffley, M., \& Mondak, J. "Linked fate and outgroup perceptions: Blacks, Latinos, and the US criminal justice system.” Political Research Quarterly 68, no. 3 (2015): 505-520.

Kinder, D. R., Sanders, L. M., \& Sanders, L. M. Divided by color: Racial politics and democratic ideals. University of Chicago Press, 1996.

Kluegel, J. R., \& Smith, E. R. "Affirmative action attitudes: Effects of self-interest, racial affect, and stratification beliefs on Whites' views.” Social Forces, 61, no. 3 (1983): 797-824.

Knoll, B. R. “¿Compañero o Extranjero? Anti-Immigrant Nativism among Latino Americans.” Social Science Quarterly, 93, no. 4(2012): 911-931.

Kravitz, David A., and Stephen L. Klineberg. "Reactions to two versions of affirmative action action among Whites, Blacks, and Hispanics." Journal of Applied Psychology 85, no. 4 (2000): 597.

Krysan, Maria. "Prejudice, politics, and public opinion: Understanding the sources of racial policy attitudes." Annual Review of Sociology 26, no. 1 (2000): 135-168.

Lavrakas, Paul J. Encyclopedia of survey research methods. Sage Publications, 2008.

Lipschutz, A. El problema racial en la conquista de América y el Mestizaje. In J. Cademártori (ed.), La economía chilena, Santiago de Chile: Cormorán, 1972.

Marquez, B. LULAC: The evolution of a Mexican American political organization. University of Texas Press, 1993.

Munguia, H. Here's What Happens When You Ban Affirmative Action in College Admissions. Five'ThirtyEight, (December 09, 2015). < https:/ / fivethirtyeight.com/features/heres-whathappens-when-you-ban-affirmative-action-in-college-admissions $>$.

Quillian, Lincoln. "Prejudice as a response to perceived group threat: Population composition and anti-immigrant and racial prejudice in Europe." American sociological review (1995): 586611.

Rabbie, Jacob M., and Murray Horwitz. "Arousal of ingroup-outgroup bias by a chance win or loss." Journal of personality and social psychology 13, no. 3 (1969): 269.

Rieder, J. Canarsie: The Jews and Italians of Brooklyn against Liberalism. Harvard University Press, 2009.

Sanchez, Gabriel R., and Edward D. Vargas. "Taking a closer look at group identity: The link between theory and measurement of group consciousness and linked fate." Political Research Quarterly 69, no. 1 (2016): 160-174.

San Miguel, Jr, Guadalupe. "The impact of Brown on Mexican American desegregation litigation, 1950s to 1980s." Journal of Latinos and Education 4, no. 4 (2005): 221-236. 
Let All of Them Take Heed: Mexican Americans and the Campaign for Educational Equality in Texas, 1910-1981. Mexican American Monograph Number 11. University of Texas Press, 1987.

Sears, David O., and Patrick J. Henry. "The origins of symbolic racism." Journal of personality and social psychology 85, no. 2 (2003): 259.

Sears, David O., Colette Van Laar, Mary Carrillo, and Rick Kosterman. "Is it really racism?: The origins of white Americans' opposition to race-targeted policies." The Public Opinion Quarterly 61, no. 1 (1997): 16-53.

Sherif, Muzafer. The robbers cave experiment: Intergroup conflict and cooperation. Wesleyan University Press, 1988.

Sherif, M., O. J. Harvey, W. R. Hood, and C. W. Sherif. Intergroup Conflict and Group Relations: The Robbers Cave Experiment. The Institute of Group Relations, OK, 1961.

Sidanius, Jim, Pam Singh, John J. Hetts, and Chris Federico. "It's not affirmative action, it's the Blacks: The continuing relevance of race in American politics." Racialized politics: The debate about racism in America (2000): 191-235.

Tajfel, H. Human groups and social categories: Studies in social psychology. Cambridge University Press, 1981.

Tajfel, Henri, John C. Turner, William G. Austin, and Stephen Worchel. "An integrative theory of intergroup conflict." Organizational identity: A reader (1979): 56-65.

Telles, E. Pigmentocracies: Ethnicity, race, and color in Latin America. UNC Press Books, 2014.

Telles, Edward, and Tianna Paschel. "Who is black, white, or mixed race? How skin color, status, and nation shape racial classification in Latin America." American Journal of Sociology 120, no. 3 (2014): 864-907.

Tesler, M. Racial Priming with Implicit and Explicit Messages. Oxford Research Encyclopedia of Politics. Oxford University Press, 2017.

Tesler, Michael. "Priming predispositions and changing policy positions: An account of when mass opinion is primed or changed." American Journal of Political Science 59, no. 4 (2015): 806824.

Tuch, Steven A., and Michael Hughes. "Whites' racial policy attitudes in the twenty-first century: The continuing significance of racial resentment." The ANNALS of the American Academy of Political and Social Science 634, no. 1 (2011): 134-152.

Turner, J. C. "Social categorization and the self-concept: a social cognitive theory of group behavior/Advancer in group process." Theory \& research/Ed. By Lawler. Greenwich, Connecticut, 2 (1985): 365-412. 
Uhlmann, Eric, Nilanjana Dasgupta, Angelica Elgueta, Anthony G. Greenwald, and Jane Swanson. "Subgroup prejudice based on skin color among Hispanics in the United States and Latin America." Social Cognition 20, no. 3 (2002): 198-226.

Vargas, Nicholas. "Off white: Colour-blind ideology at the margins of whiteness." Ethnic and Racial Studies 37, no. 13 (2014): 2281-2302.

Weeden, Jason, and Robert Kurzban. "Self-interest is often a major determinant of issue attitudes." Political Psychology 38 (2017): 67-90.

Weiss, K. UC law schools' new rules cost minorities spots. Los Angeles Times, 15 (1997).

\section{Appendix}

The experiment fielded on August 6-10, 2019 with a sample of 1,107 Latinos and 727 non-Hispanic whites. ${ }^{5} 614$ Latinos identified as white, 493 did not. White Latinos were excluded from all OLS regression models studying non-Hispanic whites. The sample provider was Lucid, an online panel provider. The sample was pre-stratified and the resulting completed interviews mirror the national population of Latinos as reflected in the American Community Survey. The average interview length equaled approximately 18 minutes. The experiment followed a 1x3 design: a control group and two experimental conditions.

Table A1, below, shows that the main effects model included in the text holds when including controls. Table A2 illustrates the descriptive summary statistics for the 727 non-Hispanic white included in the analysis. Table A3 shows the descriptive summary statistics for the 1,107 Latinos in the study. Table A4 shows the balances of the demographics across the two treatments and the control framing. The summary descriptive statistics show that across all groups (non-Hispanic whites, Latinos, and per each treatment/control) the sample was slightly more liberal than conservative, slightly more Democratic than Republican, and slightly more female.

\footnotetext{
${ }_{5}$ The large sample size for the experiment was determined based on a power analysis for a small effect ( $p<0.05$, power of 0.8 ), and to ensure a broader subgroup representation by implementing gender within age quotas.
} 
Table A1: Support for Affirmative Action among Whites and Latinos DV:Affirmative Action

\begin{tabular}{|c|c|c|c|c|}
\hline \multirow{3}{*}{ Latino treatment } & $\underline{\text { Whites }}$ & & $\underline{\text { Latinos }}$ & \\
\hline & -0.13 & $* * *$ & 0.002 & \\
\hline & $(0.02)$ & & $(0.02)$ & \\
\hline \multirow[t]{2}{*}{ Black treatment } & -0.103 & $* * *$ & -0.042 & $* *$ \\
\hline & $(0.02)$ & & $(0.02)$ & \\
\hline \multirow[t]{2}{*}{ Racial Resentment } & -0.406 & $* * *$ & -0.332 & $* * *$ \\
\hline & $(0.04)$ & & $(0.03)$ & \\
\hline \multirow[t]{2}{*}{ Female } & 0.024 & & 0.004 & \\
\hline & $(0.02)$ & & $(0.02)$ & \\
\hline \multirow[t]{2}{*}{ Education } & 0.046 & & -0.018 & \\
\hline & $(0.04)$ & & $(0.03)$ & \\
\hline \multirow[t]{2}{*}{ Income } & -0.066 & $*$ & -0.049 & * \\
\hline & $(0.04)$ & & $(0.03)$ & \\
\hline \multirow[t]{2}{*}{ Age $30-44$} & 0.053 & $*$ & 0.002 & \\
\hline & $(0.03)$ & & $(0.02)$ & \\
\hline \multirow[t]{2}{*}{ Age $45-64$} & 0.042 & & -0.001 & \\
\hline & $(0.03)$ & & $(0.02)$ & \\
\hline \multirow[t]{2}{*}{ Age 65p } & 0.005 & & -0.025 & \\
\hline & $(0.03)$ & & $(0.05)$ & \\
\hline \multirow[t]{2}{*}{ Party ID (GOP=1) } & -0.09 & $* *$ & -0.101 & $* * *$ \\
\hline & $(0.04)$ & & $(0.03)$ & \\
\hline \multirow[t]{2}{*}{ Ideology $($ Conservatism $==1)$} & -0.084 & $*$ & -0.096 & $* * *$ \\
\hline & $(0.04)$ & & $(0.03)$ & \\
\hline \multirow[t]{2}{*}{ Constant } & 0.985 & $* * *$ & 1.021 & $* * *$ \\
\hline & $(0.04)$ & & $(0.03)$ & \\
\hline $\mathrm{N}$ & 727 & & 1107 & \\
\hline Adjusted R square & 0.261 & & 0.189 & \\
\hline F stats & 24.303 & & 24.464 & \\
\hline
\end{tabular}

${ }^{* * *} \mathrm{p}<0.01 ;^{* *} \mathrm{p}<0.05 ;^{*} \mathrm{p}<0.10$ (two tailed)

Robust standard errors in parentheses. 
Table A2. Descriptive Statistics (Whites Non Hispanics)

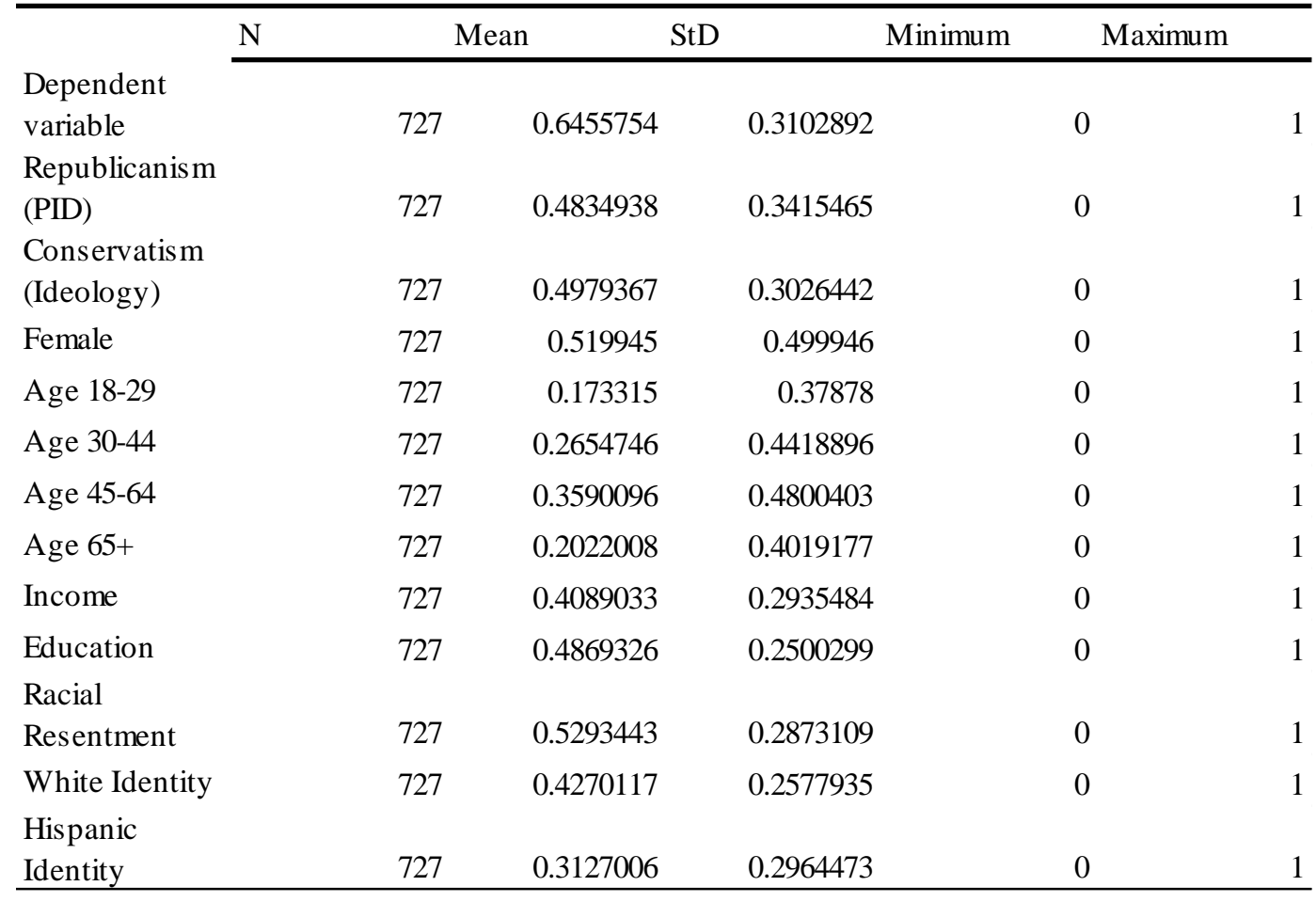

Table A3. Descriptive Statistics (Hispanics)

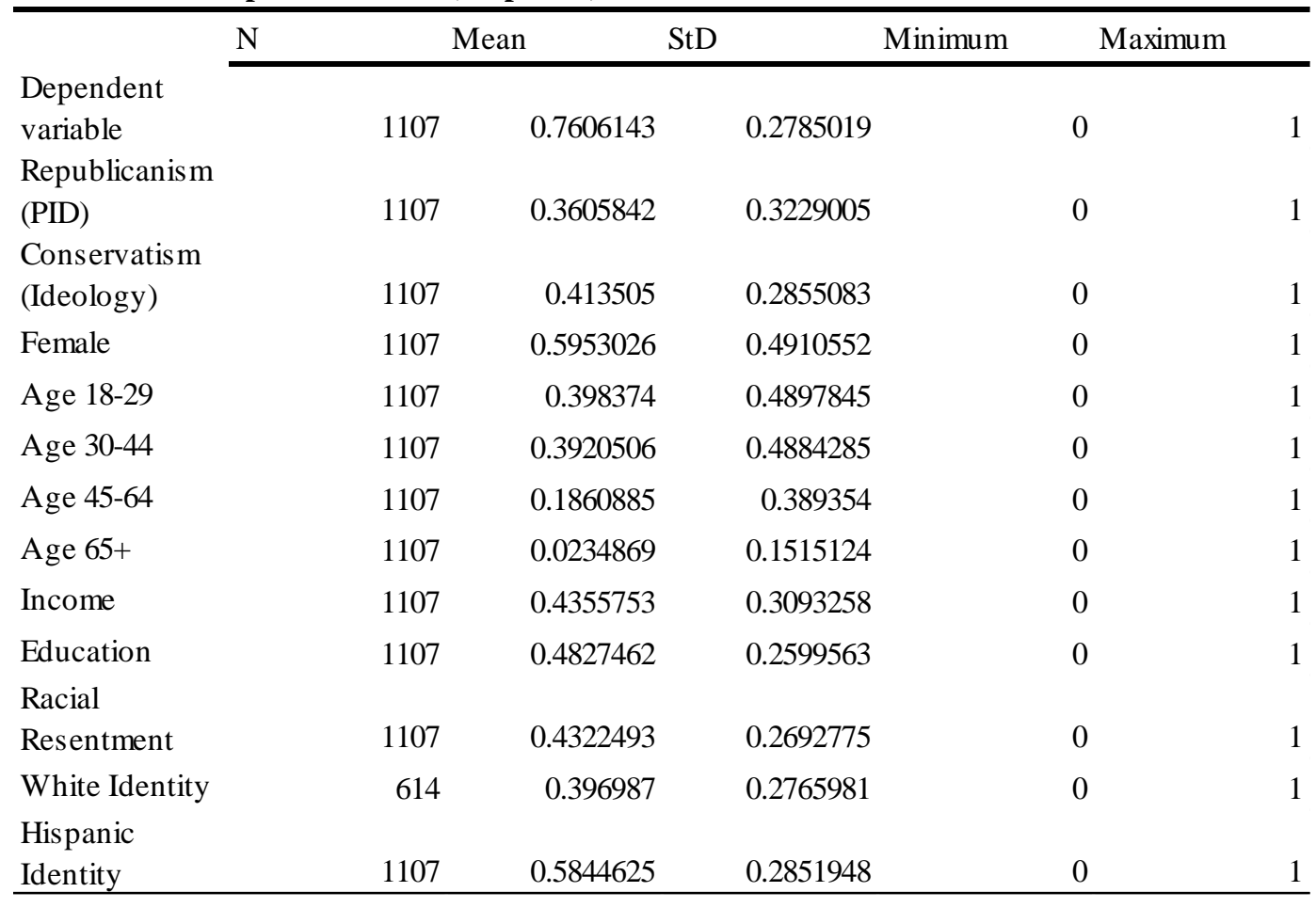




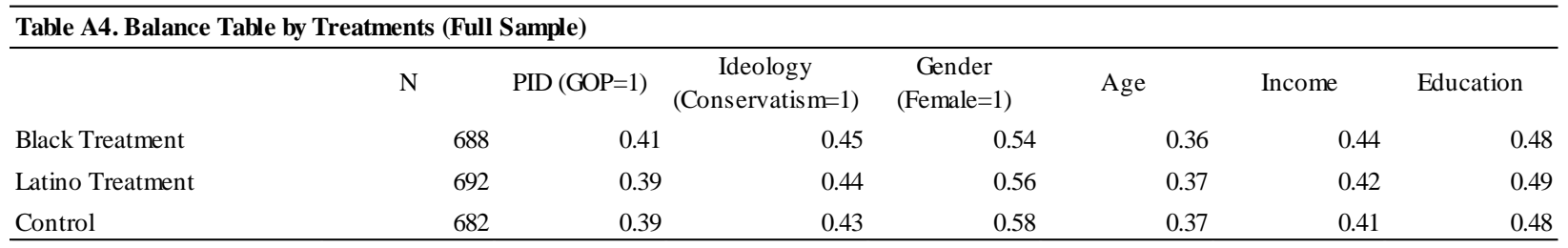

All individuals answered four items measuring levels of racial resentment before the affirmative action item. White respondents answered four items measuring White in-group identity, and Latino respondents answered three items measuring Latino in-group identity. Latino respondents who selfidentified as white also answered the four white identity items in addition to the three Latino identity items. The analyses include controls for age, gender, education, income, partisan affiliation, and political ideology.

\section{Dependent variables}

Level of Support/Opposition to Affirmative Action Policies

Control Item: "Generally speaking, to what degree do you support or oppose affirmative action programs designed to help low income people get better jobs and education?"

Latino Treatment Item: "Generally speaking, to what degree do you support or oppose affirmative action programs designed to belp Latinos get better jobs and education?"

African-American treatment: "Generally speaking, to what degree do you support or oppose affirmative action programs designed to belp African-Americans get better jobs and education?"

Racial Resentment Index (Cronbach's alpha: 0.71)

For each of the following statements, please indicate if you think the statement is very true, somewhat true, slightly true, or not at all true.

Irish, Italians, Jewish and many other minorities overcame prejudice and worked their way up. Blacks should do the same without any special favors. ${ }^{6}$

Generations of slavery and discrimination have created conditions that make it difficult for blacks to work their way out of the lower class.

Over the past few years, blacks have gotten less than they deserve.

\footnotetext{
${ }^{6}$ Critics have hammered analyses that use this item to predict affirmative action beliefs because this particular item is so close in content to affirmative action it may make for a tautological analysis. I ran all models present here excluding this item from the racial resentment index. The Cronbach's alpha with the 3-item RR index was 0.62 and all results across all models held at the same levels of statistical significance.
} 
It's really a matter of some people not trying hard enough; if blacks would only try harder they could be just as well off as whites.

Latino Identity Index (Cronbach's alpha: 0.80)

Do you think what happens to Latinos in this country will have something to do with what happens in your life?
All the time
Often
Sometimes
Never

To what extent does your identity as Latino or Hispanic influence your daily decisions?

Extremely influential

Very influential

Somewhat influential

Slightly influential

Not at all influential

How important to your identity is being of Latino or Spanish / Hispanic heritage?

Extremely important

Very important

Moderately important

Slightly important

Not at all important

White Identity Index (Cronbach's alpha: 0.82)

How important to your identity is being of white heritage?

Extremely important
Very important
Moderately important
Slightly important
Not at all important

To what extent does your identity as white influence your daily decisions?

Extremely influential

$V$ ery influential

Somewhat influential

Slightly influential 
Not at all influential

When talking about people of white heritage, how often do you say "we" instead of they?

Always
Often
Sometimes
Rarely
Never

Do you think what happens to white people in this country will have something to do with what happens in your life?

All the time

Often

Sometimes

Never

\section{Demographics}

Age: What is your age? [Younger than 18; 18-29; 30-44; 45-64; 65 or older]

Latino ID: Are you Spanish, Hispanic, or Latino? [Yes; No]

Race ID: Which one of the following describes you the most? Are you [White; Black or African-American; Asian; Middle Eastern or North African; Native American; Other]

Gender: Are you [Female; Male]

Education: What is the last grade of school you completed? Less than high school; High school; Some college; College degree; Some graduate education; Post graduate degree]

Income: In which group does your total household income fall? LLess than \$10,000; \$10,000-\$19,999; $\$ 20,000-\$ 29,999 ; \$ 30,000-\$ 39,999 ; \$ 40,000-\$ 49,999 ; \$ 50,000-\$ 59,999 ; \$ 60,000-\$ 69,999$; $\$ 70,000-\$ 79,999 ; \$ 80,000-\$ 89,999 ; \$ 90,000-\$ 99,999 ; \$ 100,000-\$ 149,999 ;$ More than $\$ 150,000]$

Partisan Affiliation: Generally speaking, do you usually think of yourself as [Strong Democrat; Weak Democrat; Leaning Democrat; Independent; Leaning Republican; Weak Republican; Strong Republican]

Political Ideology: Generally, do you consider yourself a liberal, moderate, or conservative? (Very liberal; Somewhat liberal; Moderate; Somewhat conservative; Very conservative] 